\title{
When do liabilities from public-private partnership and concession contracts become the part of the general government debt?
}

\author{
ANTO BAJO Institute of Public Finance \\ DAMIR JURIČIĆ Agency for Investments and Competitiveness
}

The use of concessions and public-private partnerships (PPPs) to finance public investments is often motivated by government's desire to avoid borrowing and any increase of the budget deficit and general government debt. The purpose of this paper is to show the statistical treatment of transactions resulting from concession and PPP contracts, which - due to the shortage of budgetary revenues - could be used more frequently in the financing of projects of national interest in the Republic of Croatia.

\section{INTRODUGTION}

In the past few years, the professional and general public in Europe and Croatia has often discussed the impact of public-private partnership (PPP) and concession contracts on general government debt. ${ }^{2}$ Those discussions can generally be divided into two categories - political and professional.

In order to operate within the budgetary constraints, public investments are often not financed directly from the government's budget, which would involve certain capital expenditures that are usually financed by borrowing, resulting in a direct increase in the general government debt. Political discussions have mainly focused on the implementation of PPPs and concessions as desirable models

\footnotetext{
I The authors would like to thank Petar Sopek, Davor Galinec and Marko Primorac for their valuable comments and suggestions. ${ }^{2}$ Discussions mainly result from the assumption that PPP and concession contracts should not be recorded on the general government's balance sheet but kept off-balance sheet. In Croatia and other European countries, a number of PPP and concessions contracts are automatically recorded off-balance sheet. However, due to certain provisions of such contracts, it may be necessary to re-classify them on-balance sheet. The most European famous example is the PPP contract in Portugal (EPEC, 2OII) and in Croatia the concession of Zagreb International Airport and the PPP Lora Hall in Split.
} 
for financing and delivering public investments without increasing the general government debt. In the background of expert discussions, the focus was mainly on the use of PPPs and concessions to achieve greater value for money for taxpayers. From the professional debates, it can be concluded that the primary reason for choosing PPPs and concessions inheres not in the reduction of general government debt, but in an increase of the quality of public services, the reduction of budget expenditures and the more equitable distribution of costs and benefits between the existing and future generations of taxpayers.

It seems that the political approach, according to which the key argument for the application of PPPs and concessions is the financing of public investments outside the purview of the statistics of general government debt, should be corrected. For a more complete understanding of the problem, it is necessary to study Eurostat's rules on recording PPP and concession contracts.

\section{THE EUROPEAN UNION'S RULES FOR RECORDING PPP AND CONCESSION CONTRACTS}

In the Manual on Government Deficit and Debt - ESA 2010 in Chapter VI Leases, licenses and concessions - Eurostat (2014) explains the statistical treatment of concessions and PPPs, distinguishing them according to the risk of demand, i.e., changes in the volume and price of delivered public services.

A concession is a long-term (typically 30 or more years) contractual relationship between the contracting authority (usually the body or the unit of central or local government) and a company from the private sector, which aims to manage the existing or newly constructed building and charge fees from final users (Eurostat 20I4: 3OI). The concessionaire assumes the risk of demand for services and realizes the major part of its revenues from the sale of public services to final users. ESA 2OIO provides for standard concession contracts for infrastructure that can be exploited commercially. In these contracts, the company is (or several companies are) responsible for the total cost of the project - the building, operating and maintenance of the infrastructure. The costs of using the services are usually borne by final users (households, businesses, etc.) who pay tolls or other fees to the concessionaire. The concessionaire realizes most of its revenues from direct sales of goods and services and takes on several business risks (mainly the demand risk and the asset management risk).

A PPP contract is a long-term contract between contracting authorities as public partners and companies from the private sector (performers) as private partners. The public partner aims at creating conditions for the provision of public services. The private partner will construct, reconstruct, maintain, finance and manage assets (for example, schools, hospitals, prisons, projects to improve energy efficiency, etc.) in order to provide to the public partner the necessary conditions for the provision of public services (treatment, education, security, lighting of public areas, etc.) at an agreed fee. The private partner, thereby, generates most of the revenue from fees paid out directly from the budget of the public partner.

Although they are very similar by nature, Eurostat distinguishes concessions and PPPs according to the criteria of origin - in concessions, private partners generate most of their revenues in the market, as opposed to PPPs where the public partner predominantly remunerates private partners.

\section{CRITICAL DILEMMAS RELATE TO THE IMPACT OF ASSETS AND LIABILITIES ON THE GENERAL GOVERNMENT DEBT}

If the government independently funds and carries out an investment project, the capital expenditure (and consequently public deficit and debt) increase by the total value of the project's assets. The project then has a direct impact on the government's balance sheet, i.e., it is on-balance sheet. 
Concessions and PPP can be seen as alternative models of financing public projects, because such projects are not recorded in the government's financial statements, but in the financial statements of private partners (for the government they are off-balance sheet). Because of shortages of budget revenues and high budget deficits, the government finances capital investments through partnership with private entities, with the use of concessions and PPPs. However, such financing, motivated by the shortages of budget revenues and high deficits, can - in some cases - also be treated as indirect government borrowing. Regardless of whether the private partner finances the investment with debt or its own capital, if the government bears most of the risks related to that investment - the assets of the project are recorded as imputed loan ${ }^{3}$ (i.e. the potential debt) for the government. The contractual payments are treated as a loan repayment. The fact is that the government ultimately receives the property, which was not financed directly (through government borrowing) but indirectly (through a private partner) with the use of concession or PPP. Therefore, in case of classifying the project onbalance sheet, the government's debt increases by the value of total assets of the project. In other words, the assets are treated as if they are bought (and completely financed) by the public partner.

With the Manual on the European System of Accounts ESA 20IO, as a part of the excessive deficit procedure (EDP), the European Commission strives to statistically determine in what conditions assets from PPP or concession contracts can be included in the coverage (on-balance sheet) of the public sector as a liability - imputed loan.

In the case of concessions and PPPs, the state is always the legal owner of the property or the infrastructure that is given in the concession or that is constructed within the PPP. The subject of the concession and PPP contract is the economic value of assets, which can be - over the period of the contract - statistically recorded in the balance sheet of the government (public partner) or the concessionaire (private partner). The economic value of the property and its statistical treatment on- or off-balance sheet of the government, as well as its impact on the budget deficit and debt is directly dependent on the content of the contract and contractual clauses. For example, the contract may contain provisions by which the government guarantees the borrowing of a private partner. Sources of financing and provision of guarantees, as well as termination clauses in contracts, are often the key reasons for a decision on the classification of assets or liabilities on-balance sheet of the government and may result in the growth of the budget deficit and debt.

The fact that the contracting authority has entered into a PPP and/or concession contract does not necessarily mean that the contracted transaction has no impact on the general government debt. The title of the contract is completely irrelevant to the decision on whether the assets will be recorded as general government debt. What is relevant is the content of the contract, particularly those clauses related to potential risks that may be borne by the government as a public partner or concession provider.

In concession contracts the key question is: who is the economic owner of the assets ${ }^{4}$, i.e., in whose balance sheet are the assets recorded during the period of use, how are the receipts (revenues) from the contract recorded and what is their impact on the net receipts/government borrowing?

Amendments to and revisions of concession contracts can significantly affect their statistical treatment. The conditions related to the termination of a contract due to inability to meet its provisions largely determine the nature (statistical treatment) of contracts.

The concession is considered a government debt if the government has provided an explicit guarantee by which it takes more than 50 percent of the concessionaire's debt, and also if the government has

3 This is actually a hypothetical debt that is recorded as a part of the excessive deficit procedure because the project does not meet all the criteria to be recorded off-balance sheet of the public sector. The amount of debt is equivalent to the value of assets. ${ }^{4}$ By using the property, the economic owner is enjoying the benefits and taking on the risks. 
taken on most of the risks associated with the assets. The key issue is the statistical treatment (classification) of the assets involved in a PPP contract. If the assets are state-owned, then this has a direct impact on the net lending/borrowing and the debt. If the assets belong to a private partner, then this can indirectly affect the net lending/borrowing and the general government debt.

A PPP contract assumes long-term contractual relationships. The longer the maturity of the contract, the more the public partner can defer the payment of part of the costs over a longer period of time longer period of repayment of services provided through the project to the public partner (the contractual authority). An important consequence of the long maturity is a more equitable distribution of costs and benefits between the existing and future generations of beneficiaries.

In the contracted period of the PPP, the contracting authority may be the legal owner of the property (the owner of the land and buildings constructed on the land). However, the economic owner is the performer (the private partner). The economic owner is the one who - by using the property - takes over the business risks and is entitled to benefits. After expiration of the contract, the contracting authority becomes the economic owner of the property.

\section{THE PRINCIPLE OF INDIVIDUAL CONTRACT}

The PPP and concession contracts are generally not standardized. Therefore, in terms of the interpretation and the classification of transactions according to ESA 2OIO, a statistical working group of experts dealing with statistics of deficit and government debt as part of the excessive deficit procedure has the main role at the national level. For the methodological advice, the statistical group may also consult with Eurostat, which may require an inspection of the contracts signed. The provisions of the contract greatly influence the perception and the statistical treatment of transactions in the national accounts.

Special emphasis is on the individual contract, as Eurostat (within Member States this is performed by the national bureaus of statistics) issues an opinion only ex post - for contracts (with its annexes) that have already been signed and not ex ante - for working drafts of some imaginary future contracts (which in practice may not be realized). National statistical offices are competent to assess the particular contract and reach a decision on whether to include the value of the contract in the general government debt. At the national statistical office's request, all public contracting authorities signing concession or PPP contracts have to submit a copy of the contract, the provisions of which may provide a basis for the classification. In Croatia, the Croatian Bureau of Statistics (CBS) is the only institution competent for final reporting to Eurostat.

Eurostat collects the information on transactions from the quarterly fiscal statistics of national statistical offices, but also from publicly available sources from the media. Based on the available information, Eurostat may initiate the assessment of the contract.

The Member State and the national statistical office normally propose a treatment of the transaction, which may or may not be accepted by Eurostat. Providing the contractual documentation to Eurostat can significantly alter its original statistical treatment decision issued according to information available from the media. Methodological advice and opinions are published on the Eurostat website. 


\section{THE BASIC GRITERIA FOR GLASSIFYING THE MAIN RISKS OF THE PROJEGT}

The European Commission has in separate documents ${ }^{5}$ prescribed about one hundred criteria under which certain contracts are classified in the general government debt, and the main are: I. the classification of the main types of risks; 2 . the criteria relating to guarantees; and 3. other criteria.

\section{I. THE GRITERIA RELATED TO THE GLASSIFICATION OF THE MAIN TYPES OF RISKS}

Most of the risks ${ }^{6}$ of a public project are classified into three groups, relating to construction, availability of public building and the demand for public services.

Risks associated with the construction are mostly related to the cost of construction within the planned budget and within the planned period and borne by the performer.

The availability of the public building refers to the obligation of the performer to keep the constructed public building (which is used to provide public services) in good working order for the public contracting authority during the period of the contract. This relates to the risks involved in the maintenance of building and equipment, management of the building, maintaining its functionality and the like.

Demand risks for public services are related to the price and the quantity of public services delivered. Accordingly, when the demand risk is borne by the performer, he assumes the risk of revenue collection, being exposed to the risks of changes in the price and the quantity of the public services delivered.

Eurostat explicitly states that off-balance sheet treatment (outside the general government debt) is possible only if the performer - in addition to the main risk of construction - also takes on the demand risk and/or availability of the public building risk. The concessionaire usually takes on all three risks, whereas the performer in PPP usually takes on the risk of constructing and maintaining the availability of the building (property) that is the subject of the contract.

\subsection{GUARANTEES}

The public contracting authority issues guarantees for the borrowing of the private performer. Eurostat distinguishes implicit and explicit guarantees. Issued guarantees transfer the risks of the project from the performer to the contracting authority.

Explicit guarantees typically represent a potential obligation (a promise) of the contracting authority (public partner, grantor) to creditors of the performer (private partner, the concessionaire) that the contracting authority will settle all performer's outstanding liabilities if they are not settled by the performer. Such guarantees may be related to performer's loans, own sources, the minimum turnover, the fixed part of the PPP fee or the financial contribution to the concessionaire.

Implicit guarantees (hidden in the contractual provisions) do not express a clear commitment to the settlement of a performer's outstanding liabilities (e.g. loans), but rather an obligation to perform future actions, which - consequently - means that the contracting authority assumes the risk of the project.

\footnotetext{
${ }^{5}$ European System of Accounts ESA 2010 (Eurostat, 2OI3), Manual on Government Deficit and Debt (Eurostat, 20I4), and a special guidance note on the impact of energy performance contracts on government accounts (Eurostat, 20I5).

${ }^{6}$ More about the risks associated with PPP projects in APPP (2014).
} 
For example, if the performer faces financial difficulties, the contracting authority can guarantee to provide, to a certain extent (percentage), additional sources of financing together with the performer.

The focus of Eurostat's analysis is particularly on interesting guarantees arising from the termination clauses of PPP or concession contracts. If termination clauses transfer most of the project risks to the contracting authority (public partner), the value of the project's assets will be recorded as general government debt.

For example, Eurostat allows the contracting authority to assume the loans and the value of all the assets in the event of termination of the contract caused by the contracting authority's failure to meet contractual obligations, but does not allow analogous assumptions in the event of termination of the contract (concession or PPP) for which the performer is responsible. If such provisions are contracted, the value - usually equal to the value of a project's assets - is automatically recorded within the general government debt, as such provisions present a transfer of risk to the public contracting authority. Accordingly, the criterion of a predominant transfer of risk to the performer is not met.

In PPP projects based on ensuring the full functionality of the building for the provision of public services, contracting the fixed part of the PPP fee is also treated as a guarantee. The share of the fixed part of PPP fees should be treated with caution, given the obligation to satisfy the rules of predominant risk transfer to performers.

Moreover, particular attention should be paid to the termination clauses of a contract related to the bankruptcy of a private partner (for example because of mismanagement or inability to provide services under the terms of the contract for a longer period). When the private partner goes bankrupt, the entire economic value of the assets is transferred to the government, unless a contract is signed with a new partner. The provisions on termination of the contract often require the government to take over the assets, as well as all the partner's liabilities (loans).

\subsection{OTHER GRITERIA}

There are a number of other criteria, of which the most important should be pointed out.

If more than 50 percent of the risk (the "50\% rule") of project (value of the building constructed) is transferred to the performer, the transaction is recorded outside the general government debt. Regardless of whether it is a concession or a PPP, it is necessary to determine the overall risk of the project in order to prove the applicability of the 50 percent rule.

The case of the reconstruction and expansion of building is similar, In this case, the value of the investment must be at least 50 percent of the value of a newly constructed building. It is a rule of the volume of investment operation, which is particularly important for energy efficiency projects (e.g. public lighting and energy renovation of public buildings).

The other important criteria can also include cases when the public contracting authority provides financing for a portion of capital expenditure ${ }^{7}$ or reschedules and refinances loans in repayment ${ }^{8}$.

\footnotetext{
${ }^{7}$ For example, the contracting authority agrees to pay part of the capital expenditures immediately after completion of the construction phase. This is not considered a payment of works, but the financing of the portion of capital expenditures of the project. The performer has assumed the risk of construction, but with the payment of a portion of capital expenditures the tendency of banks and investors to finance the project increases.

${ }^{8}$ The rescheduling and refinancing of performer's financial liabilities is caused by the changes in the financial market (changes in interest rates or rates of return on equity), which could - based on the changes in financing cost - generate additional benefit or cost for contracting parties. In this case, it is important which contracting party assumes certain risks.
} 


\section{GONCLUSION}

The ability to record a project outside the general government budget (debt) is not and should not be the main reason for the application of PPPs and concessions. These models may be useful for public investments, but their main goals should be:

- greater value for taxpayers' money in relation to the budgetary financing;

- better relationship between quality and price of public services, both for existing and future generations of beneficiaries (taxpayers);

- more effective long-term budgetary planning due to contracted payment limits;

- increased culture of transparency in public procurement procedures and information provided to the taxpayer about the cost and the quality of public services.

Eurostat specifies the relevant rules for the assessment of whether the project should be included in the statistical coverage of the debt. Eurostat does not give ex-ante reviews of hypothetical (potential) contracts, but only carries out the ex-post assessment of the statistical treatment of already signed contracts. Therefore, in the preparation of contracts, the contracting authorities should consult with experts and specify all the contractual provisions in order to know whether the implementation of the project will have an impact on the general government debt and deficit. Likewise, since capital investments necessarily entail long-term commitments, the analysis of a contractual authority's creditworthiness to meet contractual obligations should be an integral part of the project preparation process.

In terms of institutions, the good coordination of regulatory bodies - the Ministry of Finance (for concessions) and the Agency for Investment and Competitiveness ${ }^{9}$ (for PPPs) with the CBS (as a national authority competent for the classification of the assets belonging to the project into or out of the general government debt) is of the utmost importance.

\section{LITERATURE}

APPP, 20I4. Rizici u projektima javno-privatnog partnerstva, Priručnici za pripremu i provedbu javnoprivatnog partnerstva - (identifikacija, kvantifikacija i alokacija). Priručnici za pripremu i provedbu modela javno-privatnog partnerstva, br. 8. Zagreb: Agency for Public-Private Partnership.

EPEC European PPP Expertise Centre, 20II. New Eurostat's rules on contracts that found the major part of availability payments using tolls collected by or on behalf of the government - The case of the SCUT motorway contract in Portugal.

EPEC European PPP Expertise Centre, 2015. Market Update - Review of the European PPP Market, First half of 2015.

Eurostat, 20I4. Manual on Government Deficit and Debt - Implementation of ESA 2OIO. Luxembourg: Publications Office of the European Union

Eurostat, 2015. Eurostat Guidance Note, The impact of energy performance contracts on government accounts, Directorate D: GFS and quality, 7. August.

Juričić, D., 2015. Ukupni životni troškovi kao kriteriji za sagledavanje troškova javnih investicija. Tim4Pin, (9), 8-2I.

Regulation (EU) No 549/2O13 of the European Parliament and of the Council of 21 May 2013 on the European system of national and regional accounts in the European Union - ESA 2010.

Uredba o ugovaranju i provedbi energetske usluge u javnom sektoru, NN II/I5. Zagreb: Narodne novine.

${ }_{9}^{9}$ The former Agency for Public-Private Partnership. 